\title{
ОСОБЕННОСТИ ДЕЙСТВИЯ НОВОГО РЕГУЛЯТОРА РОСТА СТИВИН НА РАСТЕНИЯ
}

\author{
Рябчинская Т.А., Зимина Т.В., Бобрешова И.Ю. \\ ФГБНУ «Всероссийский научно-исследовательский институт защцтты растений» \\ n. Рамонь, Воронежская область, Россия \\ e-mail: vniizrdirektor@mail.ru
}

\begin{abstract}
The main active ingredients and the results of studies of the mechanisms of action of the new polyfunctional biological product Stivin, created on the basis of natural plant components, are presented. It is shown that the main factor determining the direction and effectiveness of the preparation is the norm of its use. The economical patterns of plant responses to treatment with a growth regulator, depending on the dosage used, are revealed. The ambiguity of the effect preparation on the resistance of plants to various types of phytopathogens in individual crops, depending on the norm of use, has been established. The results of the effect of the drug on the productivity of the main crops, the factors that determine it, and the immune status of plants are also presented. The yield increase with a single use of the preparation reached 30 percent or more.
\end{abstract}

Keywords: plant growth regulator Stivin, directions of action, rate of application, immunization, protective effect, increase in yield

\section{Введение}

В настоящее время среди экологически безопасных средств имеется большая группа биопрепаратов, обладающих полифункциональным действием, которые обеспечивают разнообразные положительные воздействия на растения. Созданные на основе элиситоров регуляторы роста уже нашли достаточно широкое применение в сельскохозяйственной практике. К ним относятся такие препараты, как Иммуноцитофит, Альбит, Стиммунол, Силк, Вэрва, Фуролан и ряд других. Защитное действие их уступает эффективности химических фунгицидов, однако за счет полифункциональности данных препаратов их применение приводит к усилению адаптивных свойств растений к стрессовым факторам среды, позволяет повышать устойчивость растений к фитопатогенам, усиливая их иммунные реакции, а также усиливать активность ростовых и фотосинтетических процессов, что приводит в конечном итоге к увеличению урожайности сельскохозяйственных культур [Злотников, 2012; Рябчинская и др., 2008, 2015; Рябчинская, Зимина, 2017].

В ФГБНУ «ВНИИЗР» разработан полифункциональный препарат на основе комплекса элиситоров растительного происхождения (экстракты активных веществ из плодоэлементов винограда и сахарной свеклы). В отличие от других препаратов аналогичного принципа действия в состав Стивина входит несколько действующих веществ (16 протеиногенных аминокислот, ресвератрол, абсцизовая кислота, макро- и микроэлементы) в дозировках, свойственных сигнальным веществам. Наличие в биопрепарате Стивин большого количества естественных элиситоров, обусловливает взаимозаменяемость действующих веществ, а также усиление различных эффектов.

Механизмы действия регуляторов роста растений данной группы очень сложны, так как достижение результата осуществляется через само растение, в основном, при изменении биохимических процессов на уровне гормональной и иммунной систем.

Учитывая разностороннее действие регуляторов роста на растения, очень трудно проследить конкретно продвижение элиситорного сигнала, однако имеется достаточно много сведений по работе той или иной сигнальной системы клеток на биохимическом уровне [Тарчевский, 2002, Тютерев, 2002]. Нашими исследованиями доказано 
элиситорное действие ряда аминокислот, содержащихся в препарате, которое обеспечивает пролонгированный иммунизирующий эффект, сохраняющийся при фенотипическом наследовании в последующей генерации растений. При обработке растений препаратом Стивин наблюдалось четкое изменение биохимических процессов, в частности, увеличивались пероксидазная активность на клеточном уровне и накопление салициловой кислоты в качестве предикторов приобретенного иммунитета.

Действие регулятора роста оценивается по фиксированному изменению того или иного биологического показателя жизнедеятельности растительного организма. Однако, в растениеводстве главной целью является повышение продуктивности сельскохозяйственных культур, которое достигается комплексным влиянием на отдельные качества и признаки, которые в конечном итоге оказывают наиболее сильное воздействие в данном направлении (фотосинтез, рост вегетативных и генеративных органов).

Таблица 1. Математические зависимости показателей роста и развития растений озимой пшеницы от используемой дозировки Стивина при обработке в период вегетации (полиномиальная регрессия 2-3 степени)

\begin{tabular}{|l|l|}
\hline \multicolumn{1}{|c|}{ Показатели } & \\
\hline Высота растений & $\mathrm{y}=-0,0002 \mathrm{x}^{3}+0,05 \mathrm{x}^{2}-3,34 \mathrm{x}+88,83$ \\
\hline Длина второго междоузлия & $\mathrm{y}=0,0007 \mathrm{x}^{3}-0,15 \mathrm{x}^{2}+11,39 \mathrm{x}-179,84$ \\
\hline Диаметр второго междоузлия & $\mathrm{y}=0,0002 \mathrm{x}^{3}-0,04 \mathrm{x}^{2}+2,28 \mathrm{x}+4,90$ \\
\hline Длина колоса & $\mathrm{y}=-0,0005 \mathrm{x}^{3}+0,12 \mathrm{x}^{2}-9,23 \mathrm{x}+36,81$ \\
\hline Продуктивная кустистость & $\mathrm{y}=0,001 \mathrm{x}^{3}-0,26 \mathrm{x}^{2}+20,96 \mathrm{x}-463,64$ \\
\hline Площадь флагового листа & $\mathrm{y}=-0,0002 \mathrm{x}^{3}+0,04 \mathrm{x}^{2}-3,09 \mathrm{x}+74,48$ \\
\hline Синтез хлорофилла & $\mathrm{y}=-0,009 \mathrm{x}^{2}+1,22 \mathrm{x}+63,32$ \\
\hline $\begin{array}{l}\text { Продуктивность } \\
\text { фотосинтеза }\end{array}$ & $\mathrm{y}=0,001 \mathrm{x}^{3}-0,28 \mathrm{x}^{2}+23,41 \mathrm{x}-533,52$ \\
\hline Масса зерна/колос & $\mathrm{y}=-0,0009 \mathrm{x}^{3}+0,20 \mathrm{x}^{2}-15,26 \mathrm{x}+90,96$ \\
\hline Масса 1000 зерен & $\mathrm{y}=0,0002 \mathrm{x}^{3}-0,05 \mathrm{x}^{2}+3,48 \mathrm{x}+6,56$ \\
\hline Урожайность & $\mathrm{y}=-0,009 \mathrm{x}^{2}+1,40 \mathrm{x}+62,46$ \\
\hline Стекловидность зерна & $\mathrm{y}=0,002 \mathrm{x}^{3}-0,50 \mathrm{x}^{2}+41,98 \mathrm{x}-1042,30$ \\
\hline Массовая доля клейковины & $\mathrm{y}=0,001 \mathrm{x}^{3}-0,35 \mathrm{x}^{2}+27,70 \mathrm{x}-619,24$ \\
\hline Массовая доля белка & $\mathrm{y}=0,0006 \mathrm{x}^{3}-0,15 \mathrm{x}^{2}+12,42 \mathrm{x}-233,73$ \\
\hline Чммунный статус & $\mathrm{y}=-0,001 \mathrm{x}^{3}+0,35 \mathrm{x}^{2}-29,28 \mathrm{x}+820,09$ \\
\hline
\end{tabular}

Примечания: х - дозировка Стивина, мл/га; у - значения показателей, \% к контролю

Интегральный показатель урожайности зависел от нормы применения препарата при $\mathrm{R}=0,88$ [Зимина, 2019].

Влияние Стивина на продуктивность растений происходит в основном за счет усиления продуктивности фотосинтеза, увеличения количества генеративных органов (продуктивная кустистость зерновых, озерненность колосьев, бобов), а на картофеле и сахарной свекле - клубне- и корнеплодов, их массы. Причем в различных дозировках препарат может повышать продуктивность культуры за счет увеличения различных 
элементов структуры урожая. Установлено также, что сортовые особенности культур могут влиять на характер эффективного действия препарата. Так, например, в норме применения Стивина 140 мл/га при обработке вегетирующих растений картофеля достигалось увеличение урожайности клубней на 26-30 \%, но на сорте Невский эффект достигался в основном за счет усиления клубнеобразования, а на сорте Жуковский увеличения их массы. При обработке вегетирующих растений ярового ячменя урожайность культуры повышалась на 7-23\%. Защитное действие препарата варьировало в пределах 8-37\%.

На сое при однократной обработке семян или вегетирующих растений в фазу 23 тройчатых листьев в норме применения 50 мл/т, га прибавки урожая в полевых опытах составляли 11-17 \%, содержание белка в зерне увеличивалось относительно контроля на 3,6 \%. На сахарной свекле прибавки урожая достигали 33 \%, защитное действие варьировало в пределах 30-55 \%. Прибавка урожая подсолнечника при обработке вегетирующих растений составляла 32 \% при повышении масличности семян на $20 \%$. Отмечено также антистрессовое действие препарата на сахарной свекле при однократном совмещении его с гербицидами, что позволяло повысить продуктивность культуры в сравнении с применением одних гербицидов на $11 \%$.

Защитная функция препарата Стивин, аналогично, как и по другим направлениям действия, тесно связана с нормой его применения. Кроме того, эффективность препарата зависела от инфекционного фона и вида патогена. На высоком инфекционном фоне иммунизирующее действие препарата, как правило, не превышало 10 \%, а при низкой степени проявления заболевания достигало 65-75 \% (корневые гнили на озимой пшенице, бактериозы на картофеле).

Известно, что препараты-иммуноиндукторы при нанесении на растения индуцируют проявление в них неспецифической (горизонтальной) устойчивости к различным патогенам [Тютерев, 2002.]

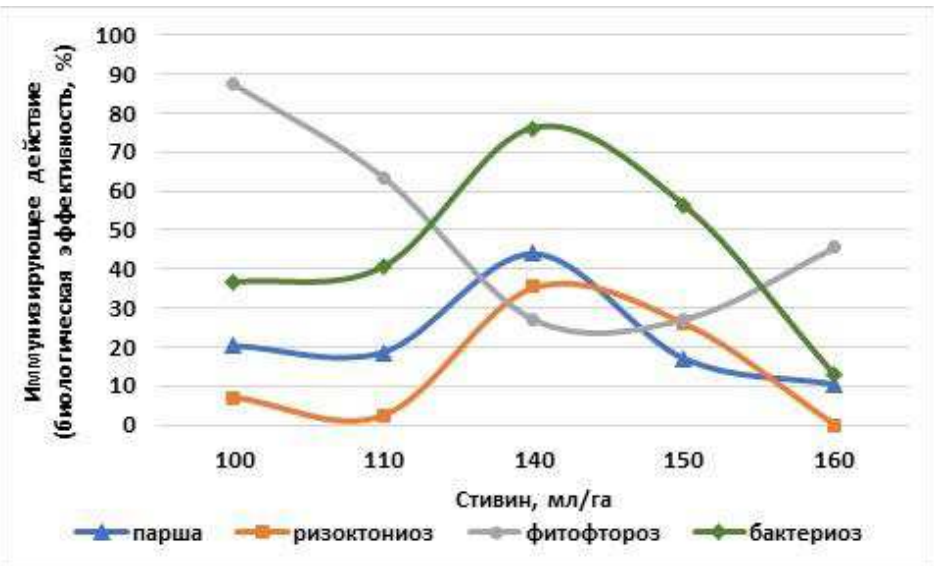

Рис. Иммунизирующее действие Стивина относительно комплекса заболеваний на клубнях картофеля нового урожая

Тем не менее, при обработке разных культур Стивином наблюдались существенные различия в иммунных реакциях растений по отношению к отдельным видам фитопатогенов в зависимости от дозировки регулятора роста. При этом, в определенных нормах применения наблюдалось сходное иммунизирующее действие препарата по отношению к разным фитопатогенам. Так, на картофеле в случае 
возбудителей парши обыкновенной, ризоктониоза и бактериоза наибольшее защитное действие была отмечено при норме применения 140 мл/га, но в этой же дозировке устойчивость к фитофторозу была недостаточно высокой (рис.)

Такое явление отмечалось нами при исследованиях эффективности защитного действия и других элиситорных регуляторов роста растений [Рябчинская, 2012].

Результаты исследований особенностей действия препарата Стивин и его эффективности, а также установленные оптимальные технологические регламенты применения позволяют сделать заключение о его перспективности для использования как в интенсивных технологиях возделывания основных сельскохозяйственных культур, так и в системе органического земледелия. В настоящее время препарат находится на стадии освоения производства и государственной регистрации.

\section{Библиография}

1. Злотников, А.К. Разработка и комплексная характеристика полифункционального препарата Альбит для защиты растений от болезней и стрессов: дис. д-ра с-х наук: 06.01.07. Воронеж, 2012. Т. 1. С. 447.

2. Зимина Т.В. Влияние биологического регулятора роста Стивин

3. на продуктивность сельскохозяйственных культур: автореф. дис. к.с.-х.н. Рамонь, 2019. $25 \mathrm{c}$.

4. Рябчинская Т.А., Харченко Г.Л., Саранцева Н.А., Бобрешова И.Ю. К вопросу оценки эффективности фитоактиваторов // Биологическая защита растений - основа стабилизации агроэкосистем: матер. докл. Междунар. науч.-практич. конф. «Биологическая защита растений, перспективы и роль в фитосанитарном оздоровлении агроценозов и получение экологически безопасной продукции», Краснодар, 23-25 сентября 2008 г. - Краснодар, 2008. В. 5. С. 371-373.

5. Рябчинская Т.А. Полифункциональные фитоактиваторы и их место в биоинформационных технологиях // Информ. бюл. ВПРС МОББ: матер. между-нар. симп. «Защита растений - проблемы и перспективы», Кишинев, 30-31 октября 2012 года. Кишинев, 2012. В. 41. С.421-429.

6. Рябчинская Т.А., Зимина Т.В. Средства, регулирующие рост и развитие растений, в агротехнологиях современного растениеводства // Агрохимия. 2017. № 12. С. 62-92.

7. Тарчевский И.А. Сигнальные системы клеток растений. М., Наука, 2002. 294 с.

8. Тютерев С.Л. Научные основы индуцированной болезнеустойчивости растений. СПб, 2002. $328 \mathrm{c}$. 